\title{
VULNERABILITY TO CLIMATIC RISKS IN NATIONAL AND LOCAL ASPECTS
}

\author{
Valentin Răileanu ${ }^{1}$, Maria Nedealcov ${ }^{1}$, Galina Mîndru' ${ }^{1}$, Rodica \\ Cojocari $^{1}$, Olga Crivova ${ }^{1}$
}

Key words: vulnerability index, exposure, sensitivity, adaptive capacity to climate risks

\begin{abstract}
Republic of Moldova's territory's Livelihood Vulnerability Index (LVI), calculated from exposure, sensitivity and adaptive capacity to climate risks, is presented. Extreme values of climate risk factors, water supply, and statistical data on socio-demographic profile were used as the initial data. As a case study, LVI and its components for the Cogâlnic River's basin within the limits of Republic of Moldova's boundaries was extracted from the obtained maps.
\end{abstract}

\section{Introduction}

Climate change in recent decades, characterized by global warming, increasing frequency and intensity of extreme natural phenomena, severely affects the living standards of human communities in certain territories (Adelekan, 2010; Adger et al, 2004; Birkman, 2006, 2010; Constantinov et al., 2009; Nedealcov, 2013, Panda, 2009).

Torrential rains and floods, landslides, fires, earthquakes, heat and cold waves lead to the occurrence of diseases, human and economic losses and, consequently, the diminution of the livelihood of the population. The necessity of highlighting the climatic risks and the elaboration of the mitigation measures, based on the economic and social status of the territory, is crucial (Adam, 2000; Abel, 2006; Balbus et al., 2009; Balbus et al., 2009; Cardona, 2011; IPCC, 2014).

The current vulnerability to climatic risks can be expressed by a complex LVI (Livelihood Vulnerability Index), which includes several indicators from different fields (Hahn et al., 2009):

- number of natural disasters and climate variability,

${ }^{1}$ Institute of Ecology and Geography, Ministry of Education, Culture and Research of the Republic of Moldova, Chișinău. Email: marianedealcov@yahoo.com 
- health

- nutrition,

- water supply,

- indicators of the social-demographic profile,

- livelihood strategies,

- communication networks.

\section{Research materials and methods}

As initial materials, a large volume of data was used, collected at the State Hydrometeorological Service, the National Bureau of Statistics and the Civil Protection and Exceptional Situations Service (currently - the General Inspectorate for Emergency Situations).

The research methodology developed by Hahn et al., (2009), Sullivan, (2006) was used, where the LVI vulnerability index represents a balanced weighted average and each subcomponent has an equal contribution to the value of the index as a whole. Because the indicators of the above subcomponents are expressed in different units of measurement, it is necessary to standardize them, according to the formula:

$$
\text { index }_{s_{d}}=\frac{s_{d}-s_{\min }}{s_{\max }-s_{\min }}
$$

where $s_{d}$ is the annual empirical value in the territorial administrative unit $d, s_{\min }-$ the minimum empirical value, $s_{\max }$ - the maximum empirical value.

The standardized values of the subcomponents were mediated according to the formula:

$$
M_{d}=\frac{\sum_{i=1}^{n} \text { index }_{s_{d} i}}{n}
$$

where $M_{d}$ - major components for district $\mathrm{d}$, index ${ }_{\text {sdi }}$ represents sub-components, indexed by $i$, which make up each major component, $n$ is the number of subcomponents in each major component.

For each district $d$ (district, municipality, Administrative-Territorial Unit Găgăuzia) the Vulnerability Index of Existence is expressed by the formula:

$$
\mathrm{LVI}_{d}=\frac{\sum_{i=1}^{7} w_{M_{i}} M_{d i}}{\sum_{i=1}^{7} w_{M_{i}}}
$$


The weights of each major component, WMi, are determined by the number of sub-components that make up each major component and which are included to ensure that all sub-components contribute equally to LVI. The LVI index can be conceived as the Exposure, Sensitivity and Adaptive Capacity to adapt to the climatic risks of the population. Exposure is determined by the variability of the climate (indicators of the thermal and rainfall regime - extreme values, standard deviations, monthly thermal amplitudes, the frequency of extremely hot and extremely cold and dry months) and the number of natural disasters (droughts, floods, waves of cold and hot, etc.). Sensitivity depends on the water supply (accessibility, insurance), the number of the non-working population (with infants younger than 15 and older people over 59), birth rate. The adaptive capacity is expressed by the indicators of the social-economic profile (indicators in the field of education and medicine).

\section{Results and discussions}

The values of Exposure, Sensitivity, Adaptive Capacity and the LVI index on administrative-territorial units (ATU), calculated according to formulas 1-3, are shown in Table 1 as an example.

According to the data presented in figures 1-4, the districts with the lowest standardized values of exposure to climate risks are Basarabeasca (0.331), Anenii Noi (0.334) and Căușeni (0.341). The highest values are attributed to the districts Hâncești (0.443), Leova, Strășeni (0.418), Drochia (0.417) and Ialoveni (0.413).The districts with the least sensitivity to climate risks are Stefan-Vodă (0.344), Criuleni (0.407), Căușeni (0.410), Cimișlia, Glodeni (0.412), Șoldanești (0.417), Anenii Noi (0.419) and Telenești (0.429). The highest sensitivity to climate risks is detected in the districts of Dondușeni (0.561), Străşeni (0.534), Ungheni (0.518), Nisporeni (0.504), Săngerei (0.502) and in the AdministrativeTerritorial Unit of Găgăuzia.

The capacity to adapt to the climatic risks with standardized values greater than 0.5 are detected in the districts of Dondușeni, Fălesti, Hâncești, Leova, the Administrative-Territorial Unit of Găgăuzia, Ialoveni, Călărasi, Rezina, Florești, Drochia and Briceni. The smallest values (about 0.4) are characteristic of the districts of Criuleni, Râșcani, Nisporeni.

The least vulnerable to climate risks with values around 0.4 are the districts from the south-east of the republic - Criuleni, Anenii Noi, Căușeni, Stefan-Vodă 
and Râscani in the North-West part. The most vulnerable is the Dondușeni district $(0,502)$, followed by the Drochia, Florești, Sângerei, Ungheni, Călărași, Strășeni, Hâncești, Leova, Găgăuzia Administrative-Territorial Units.

Table .1 Standardized values of LVI Exposure, Sensitivity, Adaptive Capacity and Vulnerability (fragment, without Transnistria)

\begin{tabular}{|c|c|c|c|c|}
\hline UAT & $\begin{array}{c}\text { Adaptive } \\
\text { capacity }\end{array}$ & Sensitivity & Exposure & Vulnerability \\
\hline $\begin{array}{c}\text { Mun. } \\
\text { Chișinău }\end{array}$ & 0,44 & 0,45 & 0,4 & 0,43 \\
\hline Mun. Bălți & 0,51 & 0,41 & 0,43 & 0,45 \\
\hline Briceni & 0,51 & 0,47 & 0,39 & 0,46 \\
\hline Dondușeni & 0,55 & 0,56 & 0,4 & 0,5 \\
\hline Drochia & 0,52 & 0,47 & 0,42 & 0,47 \\
\hline Edineț & 0,47 & 0,49 & 0,39 & 0,45 \\
\hline Fălești & 0,53 & 0,43 & 0,38 & 0,45 \\
\hline Florești & 0,51 & 0,46 & 0,41 & 0,46 \\
\hline Glodeni & 0,48 & 0,41 & 0,37 & 0,42 \\
\hline Ocnița & 0,46 & 0,4 & 0,40 & 0,42 \\
\hline Râșcani & 0,40 & 0,45 & 0,39 & 0,41 \\
\hline Sângerei & 0,48 & 0,5 & 0,41 & 0,46 \\
\hline Soroca & 0,48 & 0,43 & 0,40 & 0,44 \\
\hline Anenii Noi & 0,43 & 0,42 & 0,33 & 0,39 \\
\hline Călarași & 0,51 & 0,48 & 0,39 & 0,46 \\
\hline Criuleni & 0,41 & 0,41 & 0,38 & 0,40 \\
\hline Hâncești & 0,53 & 0,45 & 0,45 & 0,48 \\
\hline Ialoveni & 0,51 & 0,45 & 0,41 & 0,46 \\
\hline Nisporeni & 0,40 & 0,5 & 0,40 & 0,43 \\
\hline & & & & \\
\hline
\end{tabular}

The results presented in figures 1-4 by Administrative-Territorial Units can be used to evaluate Exposure, Sensitivity, Adapttive Capacity and Vulnerability to climate risks in other geographical areas, such as river basins.

As a case study, the vulnerability to climatic risks was assessed for the area of the Cogâlnic river basin within the limits of the Republic of Moldova (the area that contributes to the accumulation of water at the point of intersection of the river with the state border). The selection of this basin is appropriate due to its specific 
character. This is what Dimitrie Cantemir wrote in "Description of Moldova" "The Cogâlnic does not even have a spring of its own and can only be counted as a A complete variant of the values is shown in Figures 1-4.

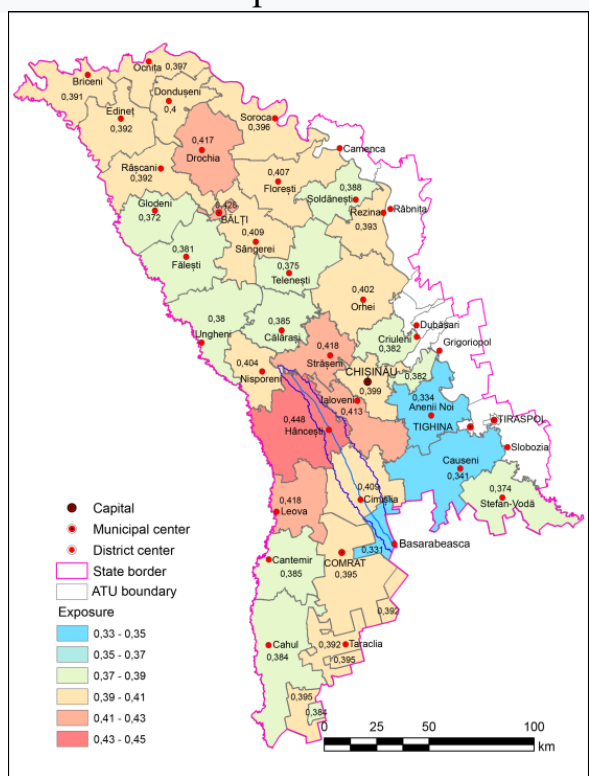

Fig. 1. The spatial distribution of the exposure to climatic risks

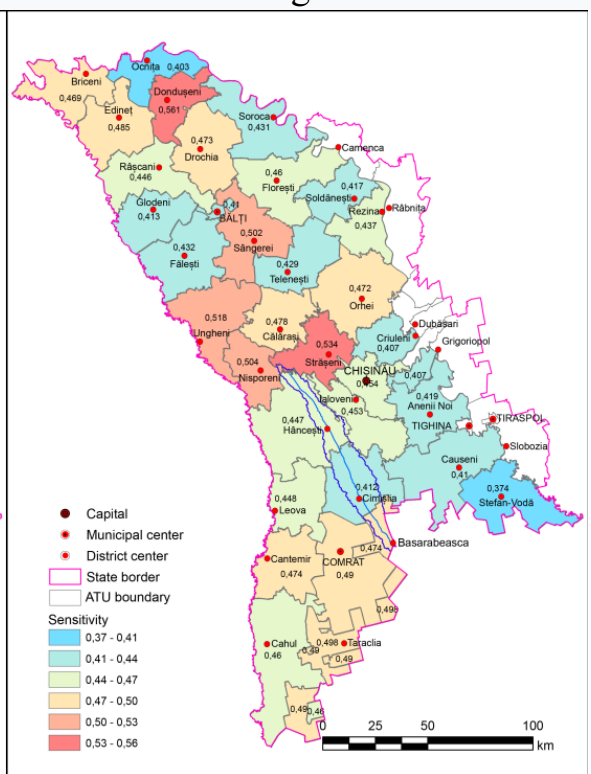

Fig. 2. The spatial distribution of the sensitivity to climatic risks 


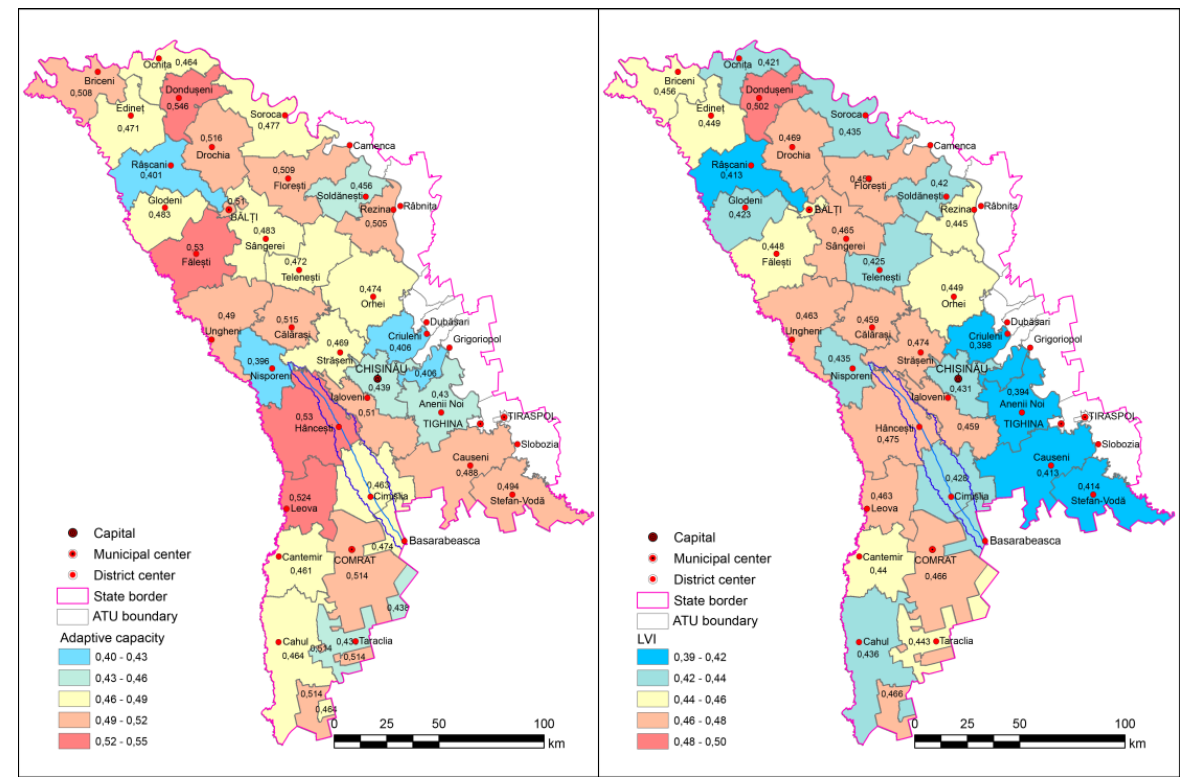

Fig. 3. The spatial distribution of the adaptive capacity to climate risks

Fig. 4. The spatial distribution of the vulnerability to climate risks

river only after the autumn rains fall; during the summer it dries up and looks like a pit, a reason why the Bugeac Tatars' cattle often die of thirst".

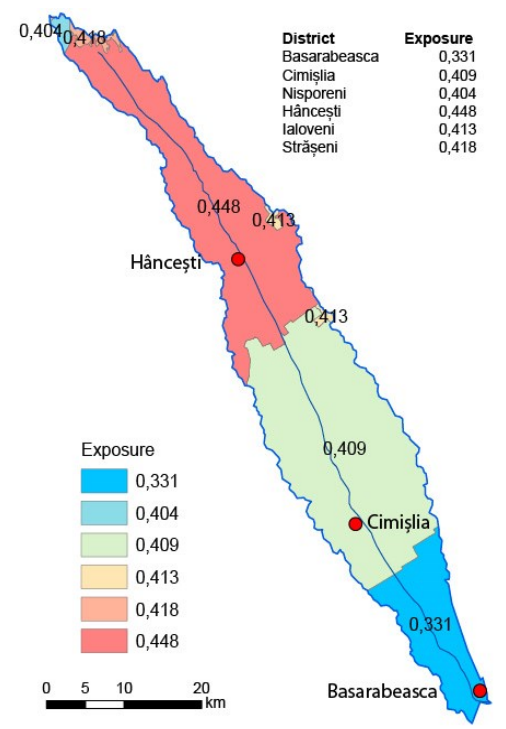

Fig. 5. Exposure of the Cogâlnic river basin

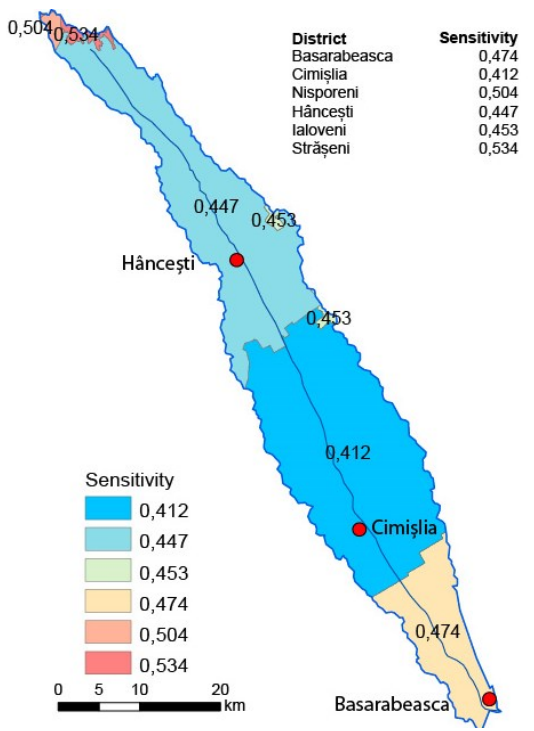

Fig. 6. Sensitivity of the Cogâlnic river basin 


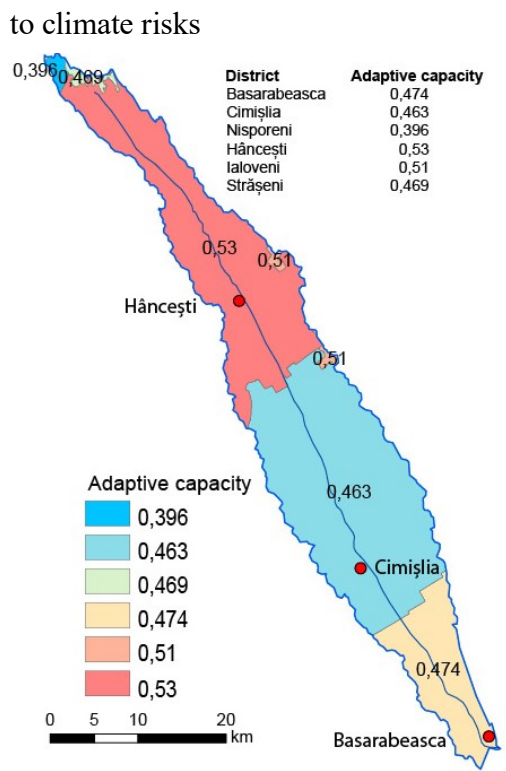

Fig. 7. Adaptive capacity of the Cogâlnic river basin to climate risks. to climate risks

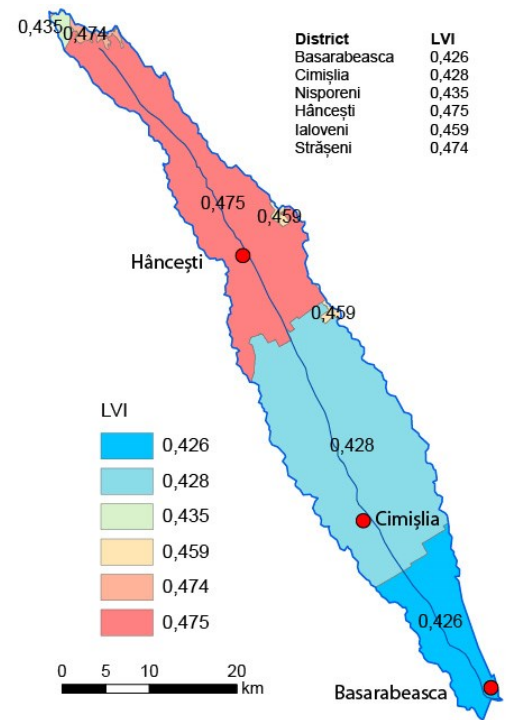

Fig. 8. Vulnerability index of the Cogâlnic river basin to climate risks

The boundaries of the basin and the Cogâlnic river within the boundaries of the country are shown in Figures 1-4, being detected using the Hydrology tool of the Spatial Analyst extension from ArcGIS. The area of the basin is approximately $1020 \mathrm{~km}^{2}$, and the perimeter - with $257 \mathrm{~km}$. The watercourse within the limits of the Republic of Moldova is approximately linear without essential meanders and extends over a length of $125 \mathrm{~km}$ from Nod-North-West to South-South-East, and the absolute altitudes fluctuate within the limits of 50-400 m. The results are shown in Fig. 5-8.

The basin of the Cogâlnic river within the boundaries of the Republic of Moldova includes parts of the Hâncești, Cimișlia and Basarabeasca districts (North, Center and South sectors) and very small portions of the Nisporeni, Strășeni and Ialoveni districts (Figs. 5-8). Comparison of exposure, sensitivity and adaptive capacity values to climate risks in the northern, central and southern parts of the basin can be made by using a radar diagram (Figure 9.) 


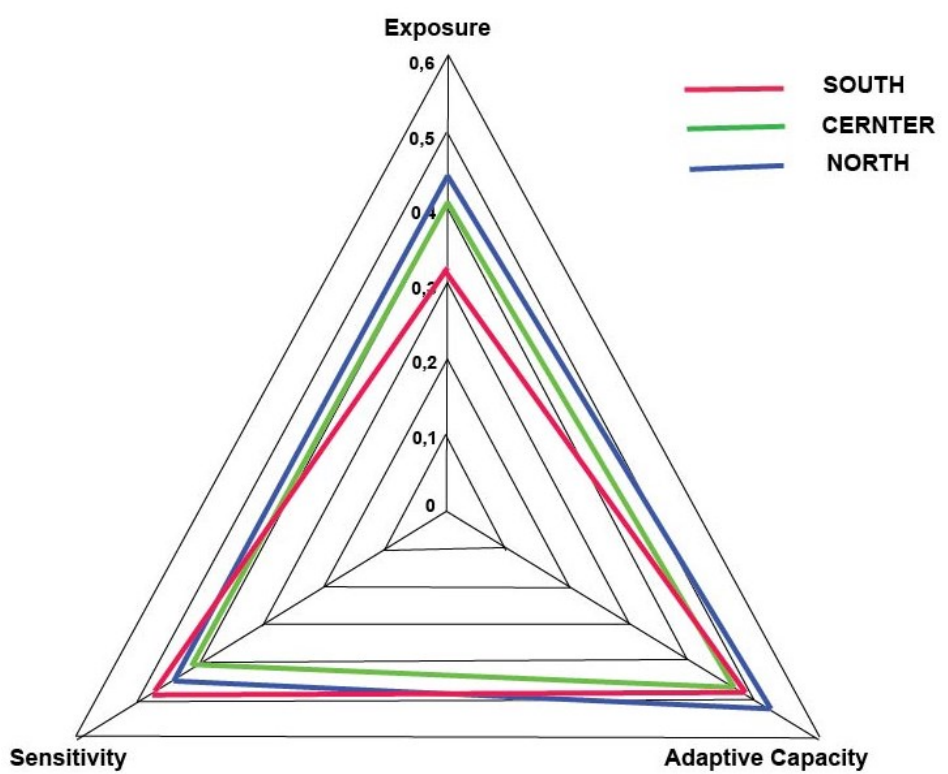

Fig. 9. Comparison of the vulnerability components of the Cogâlnic basin in the North, Center and South parts

In the North the Exposure and the Adaptive capacity are greater than those of the Center and the South, and the Sensitivity has an intermediate value. In the Center the Exposure has a higher value than in the South and lower than in the North, and the Sensitivity and the Adaptive Capacity have lower values than in the North and South. Adaptive capacity has intermediate value compared to the northern and central parts of the basin.

\section{Conclusions}

The analysis of exposure, sensitivity and capacity to adapt to climate change of administrative-territorial units can serve as a basis for developing policies and strategies to increase the standard of living of the population in all regions of the country.

The study of the vulnerability of human existence and of its components at national level can be extended to other areas of local interest, such as the river basins or the development regions of North, South Center and UTA Gagauzia.

At the same time, we consider that this research should be continued with the inclusion of more factors that characterize the exposure of the territory to the manifestation of the risks associated with climate change. 


\section{References:}

1. Abel N., D. Cumming, J Anderies. (2006), Collapse and reorganization in socialecological systems: Questions, some ideas, and policy implications. Ecologr and Society, 11(1), 17-42.

2. Adam, B. and J. van Loon. (2000), Repositioning risk; the challenge for social theory. In: The Risk Society and Beyond [Adam, B., U. Beck, and J. van Loon (eds.)]. SAGE Publications, London, UK, pp. 1-31.

3. Adelekan, I.O. (2010), Vulnerability of poor urban coastal communities to flooding in Lagos, Nigeria. Environment and urbanization, 22(2), 433-450. https://doi.org/10.1177/0956247810380141

4. Adger, W.N., N. Brooks, M. Kelly, S. Bentham, S. Eriksen. (2004), New Indicators of Vulnerability and Adaptive Capacity. TIndall Centre for Climate Change Research, Technical Report 7, University of East Anglia, Norwich, UK.

5. Balbus, J.M., C. Malina. (2009), Identifying vulnerable subpopulations for climate change health effects in the United States. Journal of Occupational and Environ. Medicine, 51(1), 33-37. https://doi.org/10.1097/JOM.0b013e318193e12e

6. Birkmann, J. (2006), Measuring vulnerability to promote disaster-resilient societies: conceptual frameworks and definitions. In: Measuring Vulnerability to Natural Hazards: Towards Disaster Resilient Societies [Birkmann, J. (ed.)]. United Nations University Press, Tokyo, Japan, pp. 9-54.

7. Birkmann, J., K. von Teicman, (2010), Integrating disaster risk reduction and climate change adaptation: key chellenges - -scale, knowledge and norms. Sustenability Sciense, 5(2), 171-184. https://doi.org/10.1007/s11625-010-0108-y

8. Cordona, O.D. (2011), Disaster risk and vulnerability: Notions and measurements of human and environmental insecurity. In: Coping with Global Environmental Change, Disasters and Security - Threats, Challenges, Vulnerability and Risks. Springer Verlag, Berlin, Germany, pp. 107-122. https://doi.org/10.1007/978-3-642-17776-7_3

9. Constantinov T., Nedealcov M., Răileanu V. (2009), Hazardurile naturale regionale Chișinău, , Cap. 3. Diferențierea teritoriului după gradul de risc climatic. CZU 551.4/5(478) R46; Tipografia „Elena V.I” SRL. ISBN 978- 9975-106-15-3. P.70-98.

10. Hahn, M.B., Reiderer A. M., Foster S. O. (2009), The Livelihood Vulnerability Index: A pragmatic approach to assessing risks from climate variability and change -A case study in Mozambique. Global Environ. Change. https://doi.org/10.1016/ j.gloenvcha.2008.11.002.

11. IPCC (2014), Climate Change 2014: synthesis report. Contribution of Working Groups I, II and III to the Fifth Assessment Report of the Intergovernmental Panel on Climate Change. Core Writing Team, Pachauri RK, Meyer LA, eds.., IPCC, Geneva, Switzerland.

12. Nedealcov, M. (2013), The Republic of Moldova Territory's Vulnerability (Exposure) to the Manifestation of Some Climate Risks. Present Environment and Sustainable Development, Vol. 7, No. 2, 2013. Pp. 13-19. 
13. Nedealcov, M. (2014), Climate Change and Anomalies Asociated in The Republic of Moldova. Present Environment and Sustainable Development, 8(1), 2013:59-68.

14. Panda, A.. (2009). Assessing Vulnerability to Climate Change in India. 44. https://doi.org/10.2307/40279163.

15. Sullivan, C., (2006). Global change impacts: assessing human vulnerability at the subnational scale. In: Presented at the International River Symposium, Brisbane.

2020 by the authors. Licensee UAIC, Iasi, Romania. This article is an open access article distributed under the terms and conditions of the Creative Commons Attribution (CC BY-NC-ND) license (https:// creativecommons.org/licenses/by-nc-nd/4.0). 